\title{
Slovenski telekomunikacijski trg: razvoj, stanje in problemi ${ }^{1}$
}

UDK: $621.39(497.12): 339.13$

\author{
Nevenka Hrovatin \\ Ekonomska fakulteta, Univerza v Ljubljani \\ nevenka.hrovatin@ef.uni-lj.si

\section{Damir Cibic} \\ Ekonomska fakulteta, Univerza v Ljubljani \\ damir.cibic@ef.uni-lj.si

\section{Matej Švigelj} \\ Ekonomska fakulteta, Univerza v Ljubljani \\ matej.svigelj@ef.uni-lj.si
}

\section{IZVLEČEK}

V članku obravnavamo stanje, razvoj in probleme slovenskega telekomunikacijskega trga na poti nadaljnje liberalizacije. $V$ primerjavi z EU se je liberalizacija telekomunikacij v Sloveniji pričela relativno pozno, saj je do formalne odprave monopola $v$ fiksni telefoniji prišlo šele $v$ začetku leta 2001, prav tako pa je bila neodvisna regulatorna agencija (ATRP), ki skrbi za zagotavljanje konkurenčnosti trga telekomunikacij, ustanovljena šele v drugi polovici leta 2001. Kljub pospešenemu ukrepanju ATRP na slovenskem telekomunikacijskem trgu, ki že kaže nekatere rezultate, bo treba za zagotavljanje konkurenčnosti slovenskega trga opraviti še veliko nalog. Prihodnje naloge na področju regulacije so tako vezane na prilagoditev veljavne slovenske telekomunikacijske zakonodaje novi zakonodaji s področja elektronskih komunikacij, ki velja v EU. Po drugi strani pa bo morala biti posebna pozornost $v$ prihodnosti še naprej posvečena zagotavljanju vstopa novih ponudnikov in spodbujanju razvoja alternativnih infrastruktur, saj bo le tako prišlo do normalizacije tržne strukture.

Ključne besede: telekomunikacije, regulacija, liberalizacija, Slovenija.

1 Članek je nastal na osnovi poročila (oktober 2003) projekta z naslovom "Spremljanje učinkov regulacije v telekomunikacijah« (pogodba ššt. 3311-02-828795, projekt št. V5-0795-02) v okviru Ciljnega raziskovalnega programa "Konkurenčnost Slovenije 2001-2006«. Za izvajanje projekta sta zagotovila sredstva Ministrstvo RS za šolstvo, znanost in šport ter Urad za makroekonomske analize in razvoj. 


\section{Hrovatin, Cibic, Švigelj \\ Slovenski telekomunikacijski trg: razvoj, stanje in problemi}

\section{Uvod}

Telekomunikacije so brez dvoma ključna industrija prihodnosti, zato ne preseneča, da so predmet zanimanja tako vlad, raziskovalcev in znanstvenikov kot različnih investitorjev (Blonski, 2002, str.1-2). Za telekomunikacije je tudi značilno, da $\vee$ zadnjih dveh desetletjih doživljajo nenehne spremembe. Vse te spremembe pa so in bodo $v$ prihodnosti vplivale na način dela in življenja ljudi. Spremembe v telekomunikacijah obsegajo tako spremembe $v$ tehnologiji kot spremembe $v$ tržni strukturi. Pri spremembah $v$ tehnologiji je treba posebej poudariti posledice digitalizacije, ki je povzročila uvedbo novih produktov, ter konvergenco med informacijskimi tehnologijami in telekomunikacijami. Po drugi strani pa se je monopolna tržna struktura z enim vertikalnim telefonskim podjetjem spremenila v strukturo raznolikih med seboj konkurirajočih si podjetij. Vse te spremembe so hkrati spremljale tudi spremembe $v$ zakonodaji in regulaciji ter nastanek neodvisnih regulatornih agencij (Cave idr., str. 3, 2002).

Tudi Slovenija je stopila na vlak tehnoloških sprememb ter postopne liberalizacije telekomunikacij, ki je bila spodbujena s pomočjo sprejete zakonodaje. $V$ primerjavi z EU se je liberalizacija telekomunikacij v Sloveniji pričela relativno pozno, saj je do formalne odprave monopola $v$ fiksni telefoniji prišlo šele $v$ začetku leta 2001, prav tako pa je bila neodvisna regulatorna agencija ustanovljena $\vee$ drugi polovici leta 2001. Namen članka je prikazati razvoj, stanje in probleme slovenskega telekomunikacijskega trga.

$\checkmark$ prvem delu članka je prikazan razvoj telekomunikacijskega trga $\vee$ Sloveniji na področju fiksne in mobilne telefonije. $\vee$ drugem delu je navedenih nekaj primerjav, ki kažejo na razvitost $v$ primerjavi z izbranimi državami. $\vee$ nadaljevanju so nato opisani predmet, metodologija regulacije in regulacijski organ. Hkrati so prikazani tudi glavni ukrepi, ki jih je izvajala ATRP za povečanje konkurenčnosti telekomunikacijskega trga. $V$ zadnjem delu so podani ocene učinkov in napotki za nadaljnje vodenje politike liberalizacije.

\section{Razvoj telekomunikacijskega trga v Sloveniji}

Slovenski telekomunikacijski trg, merjen s prihodki od prodaje, je v letu 2002 znašal približno 600 milijonov evrov, kar je 2,6 \% slovenskega bruto domačega proizvoda ( $3^{\text {rd }}$ Report, 2003, str. 11$) .^{\mathbf{3}}$ Trg telekomunikacij $\vee$ Sloveniji se je primerjavi z letom 2001 v povprečju povečal za 5,2 \%. Slovenski telekomunikacijski trg

2 Če ni drugače navedeno, se v celotnem članku podatki za države EUCC nanašajo na 31. 1. 2003, medtem ko se podatki za države EU nanašajo na avgust 2002.

3 Skupina Telekom Slovenija je imela v letu 2002 več kot 575 milijonov evrov prihodkov od prodaje, kar je 95 \% vseh prihodkov od prodaje na telekomunikacijskem trgu v Sloveniji v letu 2002. 


\section{Slovenski telekomunikacijski trg: razvoj, stanje in problemi}

obsega samo $2 \%$ trga $\vee$ državah kandidatkah za članstvo $\vee$ EU $\left(E U C C^{4}\right)$. Telekomunikacijski trg se je $\vee$ državah EUCC $\vee$ letu 2002 glede na prejšnje leto $\checkmark$ povprečju povečal za $20 \%$, in sicer s približno 25 milijard evrov na 30 milijard evrov. Po drugi strani pa je trg $\vee$ državah EU rasel med 4,9 \% in $7 \%$ (8th Report, str. 9, 2002). ${ }^{\mathbf{5}}$

Največji delež telekomunikacijskega trga $\vee$ Sloveniji obsega mobilna telefonija (57 \%), kar je za 19 odstotnih točk več, kot je delež v državah EU, in za 12 odstotnih točk več, kot je $\vee$ državah EUCC-10 ${ }^{\mathbf{6}}$ (2nd Report, 2002, str. 11, 7th ReportAnnexes, 2001, str. 4). To kaže na relativno dobro razvitost mobilnih komunikacij $\checkmark$ Sloveniji. Delež mobilne telefonije se veča na račun fiksne telefonije $\vee$ državah EUCC predvsem zaradi njene slabše razvitosti v primerjavi z državami EU. Po drugi strani pa je delež prihodkov od podatkovnih storitev in zakupljenih vodov $v$ državah EUCC zelo majhen ( 5 odstotnih točk manj kot $\vee$ državah EU), vendar primerjava zadnjih treh let kaže, da počasi, vendar vztrajno rastejo (2nd Report, 2002, str. 12). V državah EU v povprečju delež fiksne telefonije presega delež mobilne telefonije, hkrati pa lahko opazimo tudi večji delež prihodkov od podatkovnih storitev in zakupljenih vodov.

\subsection{Razvoj fiksne telefonije}

V Sloveniji sta bili izdani 2 licenci za opravljanje javne govorne telefonije, vendar to dejavnost opravlja samo Telekom Slovenije (100-odstotni tržni delež), ki mu konkurira samo na področju mednarodnih klicev dvanajst operaterjev VoIP (Voice over IP) (3rd Report, 2003, str. 110). ${ }^{\mathbf{8}} \mathrm{V}$ tabeli 1 je prikazano število fiksnih priključkov Telekoma Slovenije po posameznih letih. Ob koncu lanskega leta je tako bilo 1.063.000 uporabnikov, kar je pomenilo 54,5-odstotno penetracijo, ki naj bi se po napovedih do konca letošnjega leta povzpela na 58,2 \% (Stergar, 2004).

\footnotetext{
4 Med državami EUCC so upoštevane: Bolgarija, Ciper, Češka, Estonija, Madžarska, Litva, Latvija, Malta, Poljska, Romunija, Slovaška, Slovenija in Turčija. Nekatere izmed naštetih držav EUCC so sedaj že članice EU, kljub temu pa uporabljamo izraz EUCC, saj je članek nastal pred vstopom teh držav v EU.

5 Podatek za EU predstavlja oceno rasti trga za leto 2002, ki jo je podal EITO (European Information Technology Observatory) (4,9\%), medtem ko je po napovedih IDATE rast trga v EU $7 \%$.

6 EUCC-10 so države kandidatke za članstvo v EU brez Cipra, Malte in Turčije.

7 V letu 2002 je licenco za opravljanje fiksnih javnih telefonskih storitev poleg Telekoma Slovenije pridobilo tudi podjetje Voljatel, ki pa storitev še ne ponuja (ATRP, str. 6, 2003).

8 Po trditvah Telekoma naj bi v letu 2002 aktivno delovalo 10 operaterjev VolP (Letno poročilo Telekoma Slovenije, 2002, str. 18)
} 
Hrovatin, Cibic, Švigelj

Slovenski telekomunikacijski trg: razvoj, stanje in problemi

Tabela 1: število fiksnih telefonskih priključkov Telekoma Slovenije (v tisoč)

\begin{tabular}{|c|c|c|c|c|c|}
\hline & $\begin{array}{c}\text { PSTN }^{2} \\
\text { (analogno) } \\
\end{array}$ & $\begin{array}{c}\text { ISDN }^{1} \\
\left(\mathrm{BA}^{3}+\mathrm{PA}^{4}\right) \\
\end{array}$ & Centreks & ADSL & Skupaj \\
\hline 31. 12. 1996 & 615 & 7 & I & I & 622 \\
\hline 31. 12. 1997 & 663 & 23 & I & I & 686 \\
\hline 31. 12. 1998 & 726 & 46 & l & I & 772 \\
\hline 31. 12. 1999 & 704 & 82 & 21 & I & 807 \\
\hline 31. 12. 2000 & 664 & 132 & 66 & I & 862 \\
\hline 31. 12. 2001 & 642 & 180 & 70 & I & 892 \\
\hline 31. 12. 2002 & 580 & 232 & 111 & 17 & 1010 \\
\hline 31. 12. 2003 & 563 & 276 & 130 & 34 & 1063 \\
\hline
\end{tabular}

Opombe: ${ }^{1}$ število kanalov

${ }^{2}$ javno komutirano telefonsko omrežje

${ }^{3}$ digitalno omrežje z integriranimi storitvami - osnovni dostop

${ }^{4}$ digitalno omrežje z integriranimi storitvami - primarni dostop

Vir: Stergar, 2004.

V Sloveniji je omrežje v letu 2001 doseglo 100-odstotno digitalizacijo, kar omogoča kvaliteto in uvedbo številnih dodatnih novih storitev. Pomemben kazalec razvoja fiksnega omrežja pa je tudi prisotnost linij xDSL. Slovenija ima 0,84 priključka xDSL na 100 prebivalcev. Na podlagi analize stanja na tržišču tehnologije xDSL v državah EU je Agencija (ATRP) ugotovila, da je Slovenija daleč pod povprečjem (ATRP, str.7, 2003). ${ }^{\mathbf{9}}$

\subsection{Razvoj mobilne telefonije}

Trenutno v Sloveniji na področju mobilne telefonije delujejo štiri podjetja. Na slovenskem trgu tako nastopajo trije operaterji Mobitel, d. d., Si.mobil, d. d., Western Wireless International (WWI), d. o. o., ter Debitel, d. d., ki je samo ponudnik storitev in najema omrežje podjetja Mobitel. ${ }^{\mathbf{1 0}}$

Začetki mobilne telefonije $v$ Sloveniji segajo $v$ leto 1991, ko je podjetje Mobitel začelo z izgradnjo analognega omrežja NMT. " Kot je razvidno s slike 1 se je mobilna telefonija $\vee$ Sloveniji glede na razmere $v$ svetu začela razvijati dokaj pozno

9 Razlike se kažejo tudi pri deležu konkurenčnih ponudnikov, ki v EU dosegajo kar 22-odstotni tržni delež, medtem ko $\vee$ Sloveniji storitve na področju xDSL praktično ponuja samo SiOL (Letno poročilo ATRP, 2002, str. 7).

10 Podjetje WWI na trgu nastopa pod blagovno znamko Vega.

11 Gradnja omrežja NMT je potekala v sodelovanju s Hrvaško. Posebnost našega sistema NMT je, da $\checkmark$ nasprotju z omrežji $v$ drugih državah deluje na frekvenčnem pasu $410 \mathrm{MHz}$, zato je gostovanje uporabnikov NMT možno samo na Hrvaškem. 
Hrovatin, Cibic, Švigelj

Slovenski telekomunikacijski trg: razvoj, stanje in problemi

(10 let kasneje). Tudi pri uvedbi druge generacije mobilne telefonije je Slovenija zamujala za drugimi državami (4 leta). Kljub temu pa smo v Sloveniji zaostanek uspešno nadoknadili, saj je $\vee$ Sloveniji med prvimi $\vee$ svetu $\vee$ decembru 2003 začelo delovati omrežje tretje generacije (UMTS) podjetja Mobitel. Po drugi strani pa 85-odstotna penetracija mobilnih uporabnikov presega povprečje EU kar za 10 odstotnih točk (3rd Report, 2003, str. 45).

\section{Slika 1: Tehnološki razvoj mobilne telefonije $v$ svetu in Sloveniji ter hitrost prenosa podatkov, ki jih posamezne tehnologije omogočajo}

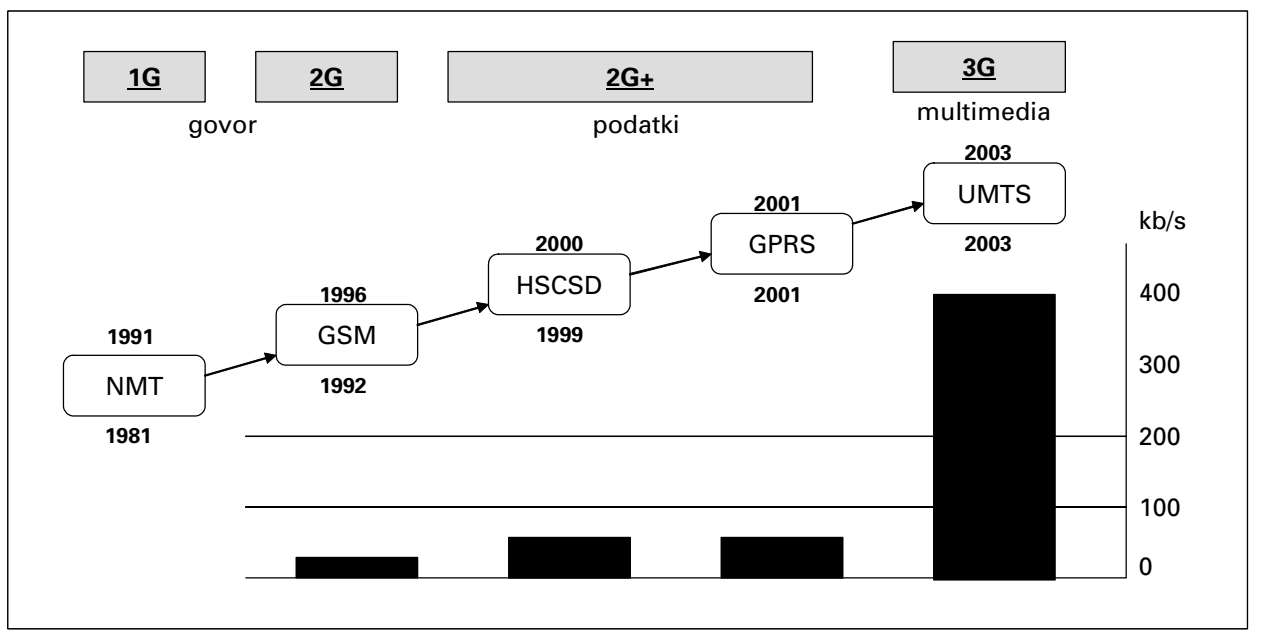

Opomba: Letnice $v$ spodnjem delu slike predstavljajo razvoj mobilnih telekomunikacij $v$ svetu, medtem ko letnice $v$ zgornjem delu slike in podatki o hitrosti prenosa podatkov veljajo za Slovenijo.

Vir: Spletna stran Mobitela.

Na slovenski trg mobilne telefonije so posamezni ponudniki vstopali postopoma. Kot smo omenili že prej, je bil prvi ponudnik mobilnih storitev na našem trgu podjetje Mobitel, ki je ponujalo prvo generacijo mobilne telefonije (NMT). Število naročnikov NMT je naraščalo do leta 1998, ko je doseglo skoraj 43.000 naročnikov. $V$ naslednjih letih je število naročnikov NMT upadalo in se ustalilo pri približno 40.000 naročnikih. Razlog za ustavitev rasti števila naročnikov je bila uvedba druge generacije mobilne telefonije (GSM) $\vee$ letu 1996, ki jo je prav tako prvo ponudilo podjetje Mobitel. ${ }^{12}$ Že $v$ letu 1997 je število naročnikov GSM presegalo število naročnikov NMT (glej sliko 2). Novembra 1998 je na trg stopilo podjetje Debitel, ki pa nima svojega omrežja. Podjetje Debitel je samo ponudnik storitev in ima v najemu omrežje podjetja Mobitel, zato njegov vstop na trg ni prinesel večjih sprememb. Večje spremembe na trgu so se začele z vstopom novega mobilnega

12 Podjetje Mobitel je v 100-odstotni lasti podjetja Telekom Slovenije, d. d., ki je v večinski lasti države. 
operaterja GSM (Si.mobil). Si.mobil ${ }^{\mathbf{1 3}}$ je začel ponujati svoje storitve konec marca 1999. Vstop novega konkurenta je povzročil cenovno vojno, kar se je odrazilo $v$ povečanju števila uporabnikov (slika 2). Pomemben vzrok za povečano rast mobilnih uporabnikov $v$ tem obdobju je bila tudi uvedba predplačniških paketov. ${ }^{\mathbf{1 4}}$ Po drugi strani pa je konkurenca na trgu povzročila tudi pospešeno uvajanje novih storitev. V decembru leta 2001 je storitve GSM začel ponujati še tretji operater mobilne telefonije (WWI), ki kljub nizkim cenam in obširni promociji ni pridobil večjega števila uporabnikov, saj sta bili zasičenost trga in penetracija že previsoki.

\section{Slika 2: število uporabnikov GSM po posameznih operaterjih od} leta 1997 do leta 2003

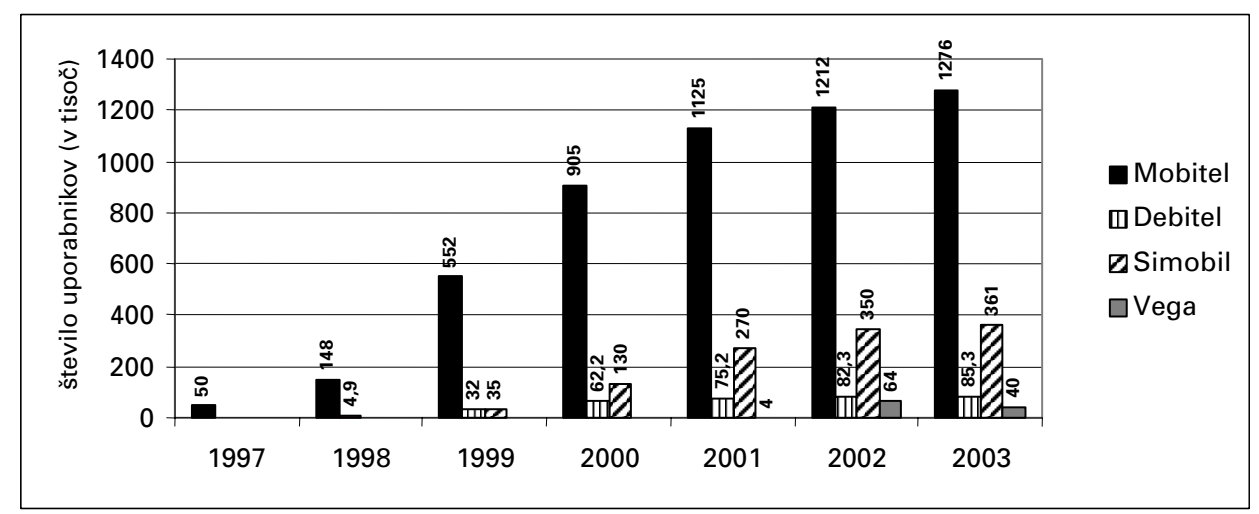

Opomba: Podatki se nanašajo na 31. 12. Podatki o številu naročnikov Vege za leto 2003 pomenijo oceno.

Vir: Stergar, 2004.

Največji tržni delež s 73 \% ima podjetje Mobitel, ki mu sledi podjetje Si.mobil z 20-odstotnim deležem, Debitel s 4,7-odstotnim tržnim deležem ter Vega z 2,2-odstotnim tržnim deležem (Stergar, 2004). Za slovenski mobilni trg je tako značilna visoka stopnja koncentracije tudi po prihodu konkurence. Razlogi za tako strukturo trga so $v$ tem, da je podjetje Mobitel praktično do aprila 1999 imelo monopolni položaj (pozen vstop konkurentov). Drugi razlog pa je $v$ visokih stroških klicev med posameznimi operaterji. $\vee$ decembru leta 2003 je Mobitel začel ponujati storitve tretje generacije mobilne telefonije (UMTS). ${ }^{15}$ Če se bo tehnologija UMTS hitro razširila, lahko pričakujemo, da bo podjetje Mobitel ohranilo svoj položaj oz. ga še okrepilo.

13 Podjetje je v večinski lasti Mobilcoma od leta 2001. V letu 2003 pa je Si.mobil podpisal tudi pogodbo o sodelovanju z družbo Vodafone.

14 Podjetje Mobitel je uvedlo predplačniške pakete (Mobi) v oktobru 1998, medtem ko je Si.mobil uvedel predplačniške pakete (Halo) leto kasneje.

$15 \mathrm{~V}$ Sloveniji je bila do sedaj podeljena samo ena koncesija za UMTS podjetju Mobitel, medtem ko se druga podjetja zanjo niso odločila zaradi previsoke koncesnine. 
Hrovatin, Cibic, Švigelj

Slovenski telekomunikacijski trg: razvoj, stanje in problemi

\section{Primerjava $z$ izbranimi državami}

Pri mednarodni primerjavi Slovenije z drugimi državami smo izbrali tri države iz EU (Avstrija, Finska, Portugalska) in tri države med kandidatkami za članstvo v EU (Češka, Poljska, Madžarska). Za izbor Avstrije, Finske in Portugalske smo se odločili zato, ker gre za manjša gospodarstva v EU. Pri tem je za Avstrijo značilna dolga zgodovina državnega lastništva $v$ vodilnem operaterju. ${ }^{\mathbf{1 6}}$ Finska nam služi kot država z dolgo tradicijo liberalizacije telekomunikacij in hkrati kot predstavnica skandinavskih držav. Portugalska pa ima po drugi strani primerljiv BDP na prebivalca s Slovenijo. Madžarsko smo izbrali, ker se je država iz vodilnega operaterja hitro umaknila, saj je prodala celoten lastniški delež. Po drugi strani pa sta Češka in Poljska primera držav, $\vee$ katerih teče proces liberalizacije telekomunikacij zelo počasi.

\subsection{Fiksna telefonija}

Primerjava Slovenije z izbranimi državami EUCC in EU kaže, da v Sloveniji na področju fiksne telefonije konkurence ni, saj to dejavnost opravlja samo Telekom Slovenije. Med izbranimi državami EUCC so tako v nasprotju s Slovenijo že prisotni alternativni operaterji, vendar je konkurenca še vedno na nizki ravni. Po drugi strani pa lahko v Avstriji, na Finskem in na Portugalskem že opazimo sadove liberalizacije, saj je konkurenca povzročila opaznejše zmanjšanje tržnega deleža vodilnih fiksnih operaterjev (3rd Report, 2003, str. 20, 8th Report-Annex I, 2002, str. 11, $14,18)$. Kljub odsotnosti konkurence pa je primerjava nominalnih cen storitev fiksne telefonije pokazala, da so cene vodilnega operaterja $\vee$ Sloveniji med najnižjimi in pod povprečjem cen ( $v$ nekaterih primerih tudi pod minimalno ceno) $v$ EU. Po drugi strani pa primerjava cen z upoštevanjem paritete kupne moči (PPP) kaže, da so storitve fiksne telefonije za končne uporabnike $v$ Sloveniji lažje dostopne kot v primerjanih državah EUCC, vendar v nekaterih primerih težje dostopne kot v državah EU. Primerjava cen nam kaže samo eno plat medalje, saj sama višina cen storitev ne pokaže stroškovne strukture.

Ker je medomrežno povezovanje eden glavnih dejavnikov konkurence na telekomunikacijskem trgu, je pomembno, da so cene medomrežnega povezovanja na ustrezni ravni. Od avgusta 2003 so cene medomrežnega povezovanja v Sloveniji na ravni povprečja v EU. ${ }^{17}$ Slovenija ima tako med primerjanimi državami najnižjo ceno medomrežne povezave na lokalni ravni $(0,77 \mathrm{c} €)$ in enojni tranzit $(1,09 \mathrm{c} €)$. Najnižjo ceno dvojnega tranzita pa ima Poljska, in sicer 1,67 c€, kar je za 7c€ manj od povprečja EU $(1,74 \mathrm{c} €)$. Precej drugačne pa so razmere $\vee$ Sloveniji pri cenah

16 Kot prevod za angleško besedo »incumbent" bomo uporabili besedno zvezo "vodilni operater«. Vodilni operater je bivši monopolni operater fiksne telefonije.

17 Znižanje cen medomrežnega povezovanja na raven povprečja EU je Telekomu Slovenije naložila Agencija za telekomunikacije, radiodifuzijo in pošto - ATRP (ATRP, 2003). 
medomrežnega povezovanja iz fiksnega $\vee$ mobilno omrežje. Cena te povezave je v Sloveniji $(23,55$ c€) za 24 \% višja od povprečja v državah EU. Tako na Češkem kot na Madžarskem so cene medomrežnega povezovanja iz fiksnega $\vee$ mobilno omrežje pod povprečjem EU ${ }^{\mathbf{1 8}}$ (3rd Report, 2003, str. 60).

Tabela 2: število linij xDSL na 100 prebivalcev v letu 2002

\begin{tabular}{|l|c|c|c|c|c|c|c|}
\hline & Slovenija & Češka & Madžarska & Poljska & Avstrija & Finska & Portugalska \\
\hline $\begin{array}{l}\text { število } \\
\text { priključkov } \\
\text { xDSL na 100 } \\
\text { prebivalcev }\end{array}$ & 0,84 & 0 & 0,3 & 0,3 & 1,9 & 2,5 & 0,2 \\
\hline
\end{tabular}

Vir: ATRP, str. 7, 2003, 3rd Report, 2003, str. 14, in lastni izračuni.

Primerjava stanja na tržišču linij xDSL kaže, da med primerjanimi državami samo na Češkem še ni linij xDSL. V tabeli 2 je prikazano število linij xDSL na 100 prebivalcev. Med primerjanimi državami ima največ linij xDSL na 100 prebivalcev Finska, medtem ko ima Slovenija 0,84 priključka xDSL na 100 prebivalcev. Na podlagi analize stanja na tržišču tehnologije xDSL v državah EU je ATRP ugotovila, da je Slovenija daleč pod povprečjem (ATRP, str. 7, 2003).

\subsection{Mobilna telefonija}

$\checkmark$ tabeli 3 smo prikazali število operaterjev mobilnih javnih radijskih storitev druge generacije (2G). $\vee$ vseh primerjanih državah so prisotni trije ali več operaterjev. Po številu operaterjev $2 \mathrm{G}$ je Slovenija primerljiva z drugimi državami. Prav tako je po stopnji mobilne penetracije Slovenija v samem vrhu. Zaostanek za državami EU se kaže predvsem pri podeljevanju licenc UMTS.

V Sloveniji je $\vee$ primerjavi z EU mobilni trg precej bolj koncentriran, saj delež vodilnega operaterja $\vee$ Sloveniji presega $70 \%$, medtem ko $\vee$ državah EU vodilni operaterji kar $\vee 10$ državah ne presega 50 \% tržnega deleža. Razlogi za to so predvsem $\vee$ poznem dodeljevanju licenc konkurentom in relativno visoke cene medomrežnih povezav med operaterji. Do podobnih anomalij kot pri podelitvi koncesij GSM pa je v Sloveniji prišlo tudi pri podelitvi licenc UMTS, ki jo ima trenutno samo vodilni operater, kar bo lahko pripeljalo do podobnega rezultata (tržnih deležev) kot pri tehnologiji GSM (Gabrovšek, 2004, str. 22).

$18 \mathrm{~V}$ primeru povezovanja iz fiksnega omrežja v mobilno se cene (tri minute, konica) nanašajo na cene mobilnega operaterja $v$ lasti vodilnega fiksnega operaterja. 
Hrovatin, Cibic, Švigelj

Slovenski telekomunikacijski trg: razvoj, stanje in problemi

Tabela 3: število operaterjev mobilnih javnih radijskih storitev v izbranih državah EUCC in EU

\begin{tabular}{|l|c|c|c|c|c|c|c|}
\hline & Slovenija & Češka & Madžarska & Poljska & Avstrija & Finska & Portugalska \\
\hline $\begin{array}{l}\text { število opera- } \\
\text { terjev 2G }\end{array}$ & 3 & 3 & 3 & 3 & 4 & 4 & 3 \\
\hline $\begin{array}{l}\text { podeljena } \\
\text { licenca UMTS }\end{array}$ & da & da & ne & da & da & da & da \\
\hline $\begin{array}{l}\text { število } \\
\text { podeljenih } \\
\text { licenc UMTS }\end{array}$ & 1 & n. p. & 0 & n. p. & 6 & 4 & 4 \\
\hline
\end{tabular}

Opombe: Podatki za izbrane države EUCC se nanašajo na 31. 1. 2003, medtem ko se podatki za zbrane države EU nanašajo na avgust 2002. Na Finskem je poleg operaterjev še 10 ponudnikov mobilnih storitev. V Sloveniji pa je poleg operaterjev še en ponudnik mobilnih storitev (Debitel).

Vir: $3^{\text {rd }}$ Report, 2003, str. 44 (za države EUCC), 8th Report-Annex I, 2002, str. 48 in 49 (za države EU).

\section{Vloga regulacije}

\subsection{Predmet regulacije}

$\checkmark$ preteklosti so infrastrukturne dejavnosti $\vee$ celoti obravnavali kot naravnomonopolne dejavnosti. Vendar novejša spoznanja na osnovi empiričnih raziskav stroškovnih funkcij kažejo, da vseh infrastrukturnih panog ni več mogoče v vseh fazah dejavnosti uvrščati med naravnomonopolne panoge (Hrovatin, 1994, str. 435). Naravni monopol v telekomunikacijah se je omejil predvsem na omrežje, ki pa bi moralo biti vsem dostopno pod enakopravnimi, preglednimi in nediskriminatornimi pogoji, saj le tako lahko pričakujemo uvedbo konkurence med ponudniki telekomunikacijskih storitev.

Liberalizacija $\vee$ telekomunikacijah je povzročila, da se je praviloma pričelo pojavljati več operaterjev, zato se je $v$ evropski in slovenski zakonodaji nadzor nad dominantnim podjetjem (več kot 50-odstotni tržni delež) nadomestil z nadzorom operaterjev s pomembno tržno močjo (OPTM) (praviloma več kot 25-odstotni tržni delež). Podrobnejši prikaz predmeta in podjetij, ki so regulirana po Zakonu o telekomunikacijah (ZTel-1) v Sloveniji smo prikazali v prilogi (tabela 4).

Ker imamo $\vee$ fiksnem javnem telekomunikacijskem omrežju samo enega ponudnika, je tu prisoten naravni monopol, čeprav smo trg 1. januarja 2001 odprli konkurenci. Zakon o telekomunikacijah (ZTel-1) določa, da ima Telekom Slovenije dve leti po uveljavitvi zakona vse obveznosti, ki jih imajo OPTM (skupna uporaba objektov, odprt dostop do omrežij, nudenje vmesnikov, zakupljenih vodov, fiksnih 


\section{Hrovatin, Cibic, Švigelj \\ Slovenski telekomunikacijski trg: razvoj, stanje in problemi}

javnih telefonskih storitev in medomrežnega povezovanja). OPTM mora dovoliti predizbiro in izbiro operaterja za medkrajevne in mednarodne klice, kar je bistveni element razveze krajevne zanke, in objavljati splošne pogoje vključno z vzorčno ponudbo za medomrežno povezovanje ter za zakupljene vode. Cene teh storitev imajo naravnomonopolni značaj, zato jih je treba regulirati.

Po drugi strani pa $\vee$ mobilnih telekomunikacijah nikjer $v$ Evropi o naravnem monopolu ni več mogoče govoriti, saj imajo vse članice EU vsaj 3 ponudnike mobilne telefonije. Tako je naravnomonopolno strukturo zamenjala oligopolna, operaterjem pa se morebitno izkoriščanje monopolne moči preprečuje z določitvijo OPTM. V Sloveniji imamo na področju mobilne telefonije dva OPTM: Mobitel in Si.mobil.

\subsection{Regulacijski organ}

V Sloveniji Agencija za telekomunikacije, radiodifuzijo in pošto RS (ATRP) skrbi za konkurenčnost in regulacijo trga telekomunikacij in elektronskih medijev. ${ }^{\mathbf{9}}$ ATRP predstavlja, zastopa in vodi direktor, ki ga na podlagi razpisa imenuje vlada za dobo petih let. Samostojnost delovanja direktorja je zagotovljena z njegovo nezamenljivostjo za dobo imenovanja, razen če gre za zakonsko sankcionirane krivdne razloge na njegovi strani oz. za osebno željo po prekinitvi funkcije. ATRP v zakonskih določbah sledi zgledu britanskih regulatorjev, ki naj bi bili pri svojem delu čim bolj samostojni in neodvisni tako od vpliva sektorskih lobijev kot tudi od vpliva državnih organov in njihovih političnih odločitev. ATRP ima tako status pravne osebe javnega prava in deluje izven pristojnega ministrstva. Delovati mora nepristransko in skrbeti za pregledno delovanje trgov $v$ interesu vseh udeležencev. ATRP izdaja dovoljenja na osnovi obvestila o pričetku dejavnosti zainteresiranim izvajalcem. Pristojna je tudi za reševanje sporov, ki nastajajo zaradi zavrnitve dostopa do omrežja oz. zaradi neustreznosti višine in strukture nadzorovanih cen (tj. cen operaterjev s PTM in cen univerzalnih storitev). Evidentira tudi pogodbe o dostopu do omrežij na podlagi zakonskih določil. Nalogo ima tudi spremljati izvajanje predpisov o ločenem računovodstvu za posamezne storitve. Pomembno pa je poudariti, da ATRP $\vee$ nasprotju z Agencijo za energijo ne določa cen, pač pa daje le soglasje $k$ cenam OPTM in zahteva njihove popravke. Dodatna funkcija ATRP na cenovnem področju pa je določanje cen univerzalnih telekomunikacijskih in poštnih storitev, ki morajo biti dostopne za vse uporabnike. ATRP je tudi odgovorna za informiranje javnosti, sodelovanje s pristojnimi organi in inšpekcijami ter mednarodnimi organi in organizacijami. ATRP ima še dodatne pristojnosti, ki izvirajo iz specifičnosti telekomunikacijskega trga. Pri nalogah ATRP je močno poudarjeno tudi zagotavljanje konkurenčnosti trgov.

19 Jeseni 2002 je v njeno pristojnost s sprejemom Zakona o poštnih storitvah prešla tudi pošta. 


\section{Hrovatin, Cibic, Švigelj \\ Slovenski telekomunikacijski trg: razvoj, stanje in problemi}

Po vzoru neodvisnih regulatornih institucij naj bi se ATRP financirala iz prispevkov nadzorovanega sektorja in ne na davčni osnovi, kar je povsem $v$ skladu z ekonomsko zahtevo "uporabnik plača in s prevladujočim modelom v EU. ${ }^{\mathbf{2 0}}$ Kljub temu pa je ta zahteva izpeljana posredno, preko proračuna, ki zbira sredstva za ATRP, nad dodeljevanjem pa bedi vlada, kar posredno omejuje deklarirano samostojnost agencije. ATRP se tako financira iz različnih pristojbin in prispevkov, ki jih plačujejo izvajalci storitev letno.

ATRP se pri svojem delu srečuje tudi s težavami. Ena izmed težav je povezana s samo strukturo zaposlenih, saj je od bivšega Urada za telekomunikacije RS prevzela 47 strokovnjakov s prvenstveno tehničnega področja, zato ji primanjkuje predvsem pravnikov in ekonomskih analitikov z ustreznimi regulatornimi znanji. ${ }^{\mathbf{2 1}}$ Po drugi strani pa ima ATRP tudi težave pri uveljavljanju diskrecijske pravice regulatorja. V letu 2002 je to pravico omejila vlada, ko je regulatorjem naložila izvajanje protiinflacijske politike kot primarni cilj. Takšen ukrep bi moral biti enkratni precedens, ki se pri politiki nadzorovanih cen nikakor ne bi smel ponoviti, če želimo ohraniti zakonsko določen status regulacijskih komisij in neodvisno regulatorno politiko. Hkrati pa se tudi naravni monopolisti v Sloveniji še slabo odzivajo na pristojnosti regulacijskih institucij in na njihovo diskrecijsko moč, kar je zlasti vidno na področju telekomunikacij. ${ }^{\mathbf{2 2}}$

\subsection{Metodologija regulacije}

EU je z vidika metod regulacije dokaj fleksibilna, saj ne predpisuje nikakršnega regulacijskega obrazca. Uveljavila je le nekatere cenovne principe, ki jih pri cenovnem nadzoru morajo upoštevati države članice. Ti principi zahtevajo, da morajo biti cene storitev:

- razvezane

- pregledne

- temelječe na objektivnih kriterijih in nediskriminatorne

- javno objavljene $v$ dnevnem časopisju in uradnem listu

- stroškovno naravnane (stroški učinkovitega zagotavljanja storitev), tako da vsebujejo tudi normalni donos na kapital

- ter ne smejo dopuščati navzkrižnega subvencioniranja med storitvami.

20 V EU sta dve državi na področju telekomunikacij uporabili 100-odstotno proračunsko financiranje (Nemčija in Francija) ter Italija 69-odstotno. Vse druge članice EU so uveljavile pretežni sektorski princip (EC, 2002c).

21 Neustrezna kadrovska struktura, premajhno število zaposlenih in pogosto tudi nezaželena povezanost z izvajalci storitev so običajne težave regulatorjev tudi v drugih državah EU. Več o tem glej Hrovatin (2001).

22 Za primer naj navedemo poskus izogibanja zakonsko predpisani cenovni regulativi. Telekom Slovenije je npr. 27. septembra 2002 v Uradnem listu RS (83/02) objavil nove cene telekomunikacijskih storitev v notranjem in mednarodnem prometu, ki naj bi pričele veljati 1. oktobra 2002, ne da bi predhodno pridobil soglasje ATRP, kot to zahteva Zakon o telekomunikacijah za operaterje s pomembno tržno močjo. Zato je ATRP z odločbo prepovedala uveljavitev cen (Kompara, 2002). 


\section{Slovenski telekomunikacijski trg: razvoj, stanje}

Vlada RS je za cene operaterjev fiksnega javnega telefonskega omrežja in storitev ter operaterjev zakupa vodov s PTM z Uredbo o metodologiji oblikovanja cen javnih telekomunikacijskih storitev in omrežij predpisala stroškovno določanje cen, $^{\mathbf{2 3}}$ ki temelji na metodi cenovne kapice za košarico storitev. To je povsem v skladu s prevladujočo prakso v EU. Večina evropskih držav (8 od 15) se je odločila za cenovno kapico, pri stroških pa države uporabljajo različne modele (EC, 2002c).

ATRP je pri izdelavi metode cenovne regulacije ostala na pol poti. Na osnovi zgoraj omenjene uredbe bi namreč morala predpisati košarico storitev, izhodiščno raven cen storitev za posamezno košarico in vrednost cenovne kapice za posamezno storitev. Na podlagi objavljenih dokumentov sklepamo, da ATRP tega še ni storila, prav tako tudi ni predpisala natančnih računovodskih načel za spremljanje stroškov. Iz 5. člena uredbe tudi izhaja, da ATRP zahteva ločeno vodenje računovodstva za posamezne storitve fiksne javne telefonije in za zakupljene vode, saj sicer operater ne more predložiti analize stroškov za posamezno storitev, za katero potrebuje soglasje ATRP. ${ }^{\mathbf{2 4}}$ ATRP je šibka prav $v$ preverjanju teh stroškov. Tudi če operater ATRP posreduje analizo stroškov, bi morala ATRP sama oz. s pomočjo zunanjih konzultantov preverjati upravičenost posameznih komponent stroškov in kriterijev za razporejanje posrednih stroškov. Velja tudi omeniti, da je EU izdala priporočila za vodenje računovodstva za medomrežno povezovanje in zakupljene vode, ki bi jih bilo $v$ primeru operaterjev s PTM treba upoštevati. Zdi se, da se ATRP pri zagotavljanju stroškovne naravnanosti cen trenutno spopada s problemom pomanjkanja informacij in časa za analitične študije, zato med drugim uporablja benchmarking z EU, ki ga druge evropske države pospešeno ukinjajo. ${ }^{\mathbf{2 5}}$ Tako je npr. ATRP znižala cene medomrežnega povezovanja na raven povprečja EU, čeprav bi morala $v$ skladu z novo zakonodajo EU cene vezati na stroške.

23 Gre za stroške učinkovitega zagotavljanja storitev, ki so sestavljeni iz dolgoročnih inkrementalnih stroškov zagotavljanja storitve in primerne količine skupnih stroškov, ki obsegajo tudi razumen donos na kapital.

24 78. člen ZTel-1 zahteva ločeno vodenje računovodstva: „Operaterji javnih telekomunikacijskih storitev in omrežij morajo za izvajanje določb o stroškovni naravnanosti cen zagotoviti ustrezno ločitev na organizacijski in računovodski ravni, da bo mogoča delitev prihodkov, odhodkov in stroškov po posameznih telekomunikacijskih storitvah, ki jih opravljajo /.../ Organizacije, ki poleg radiodifuzne opravljajo tudi druge telekomunikacijske storitve, morajo voditi za obe dejavnosti ločeno računovodstvo ..."

25 Samo ena država (Danska) je v letu 2002 pri določanju cen medomrežnega povezovanja uporabljala benchmarking z EU namesto stroškovnega principa (EC, 2002a, str. 22). Za Slovenijo poročilo (3 ${ }^{\text {rd }}$ Report) sicer navaja metodo popolnoma porazdeljenih stroškov (FDC), ki je sicer predpisana, vendar se $\checkmark$ praksi, kot že rečeno, stroški operaterjev ne preverjajo, ATRP pa je pri zadnjih poseganjih $v$ uravnovešanje cen v letu 2003 uporabila benchmarking z EU. 
Hrovatin, Cibic, Švigelj

Slovenski telekomunikacijski trg: razvoj, stanje in problemi

\subsection{Analiza izvajanja zakonskih določb in ukrepi ATRP za povečevanje konkurenčnosti trga}

Kljub liberalizaciji in deregulaciji telekomunikacij pa je za povečanje konkurenčnosti trga še vedno potrebna regulacija. Kot lahko vidimo iz tabele 4 (glej prilogo), so regulaciji na različnih področjih podvržena tista podjetja, ki imajo PTM, zato je za ustrezno zagotavljanje konkurenčnosti treba določiti podjetja s PTM. Kot že rečeno, je ZTel-1 (2001) določil Telekom Slovenije za operaterja s PTM na področju fiksnih telekomunikacij v obdobju dveh let po uveljavitvi zakona. Po drugi strani pa je ATRP svojo nalogo pri določitvi OPTM opravila na področju mobilne telefonije. 27. 11. 2002 je podjetjema Mobitel in Si.mobil izdala odločbi o OPTM. Za določitev OPTM pa je poleg kriterija o tržnem deležu skupnih prihodkov, ki naj bi bil po priporočilih EU vsaj $25 \%$, uporabila tudi druge kriterije v skladu s 67. členom Zakona o telekomunikacijah. Tako je ATRP na osnovi dopolnilnih kriterijev za OPTM določila tudi Si.mobil, ki ima sicer manjši tržni delež od $25 \%$.

Tako medomrežno povezovanje kot izbira in predizbira operaterja so uzakonjeni, vendar je $\vee$ Sloveniji prisotna le izbira in predizbira operaterja za medkrajevne in mednarodne klice, medtem ko je pri lokalnih klicih, klicih $v$ mobilna omrežja in pri klicih negeografskih številk ni. Tudi pri uveljavljanju medkrajevnih in mednarodnih klicev se je dosedanji monopolist Telekom Slovenije zahtevam upiral in postopke zavlačeval.

Tudi razveza krajevne zanke, ki naj omogoča večjo konkurenčnost na najmanj konkurenčnih lokalnih trgih, je v Sloveniji uzakonjena z ZTel-1 (65. člen). Operaterji fiksnega javnega telefonskega omrežja s PTM morajo objaviti in ažurirati vzorčno ponudbo za razvezan dostop do njihove krajevne zanke in pripadajočih naprav. Elemente, ki jih mora vsebovati takšna ponudba, določi ATRP. Za zdaj na internetnih straneh Telekoma Slovenije ni mogoče zaslediti takšne vzorčne ponudbe, čeprav 3. poročilo o napredku kandidatk navaja, da obstaja osnutek takšne vzorčne ponudbe ( $3^{\text {rd }}$ Report, str. 112). Zakonsko določena razveza krajevne zanke pa se tudi sicer $v$ praksi še ne izvaja, saj nobena krajevna zanka še ni razvezana.

Zahteva evropske in slovenske zakonodaje storitev fiksnega javnega telefonskega omrežja in storitev operaterjev s PTM je, da morajo biti cene oblikovane ločeno za individualne storitve, tako da uporabniku ni treba plačevati funkcij, ki jih ne uporablja (75. člen ZTel-1). To imenujemo razvezanost cen. Zdi se, da zakonsko zahtevana razvezanost cen $\vee$ Sloveniji še ni popolnoma uveljavljena. Kot primer lahko navedemo uporabo storitev ADSL, ki jo nudi Telekom Slovenije. Če želi uporabnik uporabljati storitev ADSL, mora pred tem postati uporabnik storitve ISDN (plača priključitev), čeprav je pri ADSL ne uporablja. Takšno cenovno politiko z vezanjem cen dopušča Telekomu Slovenije po eni strani odsotnost konkurence, 


\section{Hrovatin, Cibic, Švigelj \\ Slovenski telekomunikacijski trg: razvoj, stanje in problemi}

po drugi strani pa neaktivnost oz. neukrepanje ATRP, ki bi morala zahtevati razvezo cen.

Ena izmed zahtev EU na področju cenovne politike je tudi uravnoteženje cen storitev s stroški njihovega izvajanja. V nadaljevanju podajamo sklepne ugotovitve o stanju uravnovešanja cen $\vee$ Sloveniji. ${ }^{\mathbf{2 6}}$

- $\quad$ ATRP si je vse od marca 2002 prizadevala znižati cene medomrežnega povezovanja za dostop do omrežja Telekoma Slovenije, z odločbo, veljavno od 1. avgusta 2003, pa ji je dokončno uspelo znižati nivo teh cen na povprečje cen $\vee$ EU. Cene za dostop do omrežja so bile višje od cen lokalnih klicev, kar pomeni, da je bila s takšno cenovno politiko vsakršna konkurenca onemogočena. Opozoriti velja, da je bilo pri uravnovešanju cen uveljavljeno načelo benchmarkinga, čeprav bi bilo ustrezneje uporabiti stroškovno načelo. Kljub temu pa je takšen poseg ATRP treba oceniti kot velik dosežek na področju uravnovešanja cen in povečevanja konkurenčnosti na področju fiksnega javnega telekomunikacijskega omrežja.

- Iz cenovne primerjave cen medomrežnega povezovanja iz fiksnega $v$ mobilno omrežje sledi, da so v Sloveniji te cene občutno previsoke in da ATRP na tem področju še ni uveljavila svoje regulacijske diskrecijske pravice posega $\vee$ cene. Kot že rečeno, cena te povezave $\vee$ Sloveniji $\left(23,55\right.$ c€) za $24 \%$ presega povprečje EU. ${ }^{\mathbf{2 7}}$

- Za cene medomrežnega povezovanja za klice iz enega mobilnega omrežja v druga mobilna omrežja lahko domnevamo, da so bili ti klici v preteklosti občutno predragi. Verjetno namreč je, da so mobilni operaterji vzdrževali nerealno nizke cene klicev znotraj svojega omrežja in jih subvencionirali z visoko ceno klicev $v$ druga mobilna omrežja. Vsekakor pa takšna ugotovitev ostaja le $v$ obliki domneve, saj bi njena preveritev zahtevala natančno stroškovno analizo. Do ugotovitve, da so cene medomrežnega povezovanja previsoke, je prišla tudi ATRP, ki je z odločbo mobilnima operaterjema s PTM naložila, da morata najkasneje do 1. septembra 2003 uveljaviti novo, nižjo ceno za zaključitev klica iz drugega mobilnega omrežja v svojem mobilnem omrežju.

- $\quad$ ATRP je posegla tudi na področje zakupljenih vodov in že v letu 2002 dvakrat znižala cene za zakup vodov $v$ razponu od 0,7 do $67 \%$ pri domačih zakupljenih vodih in pri večini nacionalnega dela mednarodnih zakupljenih vodov (ATRP, 2003). Te cene so sedaj nižje od povprečja EU ter izbranih države kandidatk za analizo oz. po upravičenih trditvah ATRP med najnižjimi v Evropi.

26 Natančna predstavitev ukrepov ATRP na tem področju in gibanje cen je v ATRP (2003).

$27 \vee$ primeru povezovanja iz fiksnega omrežja $v$ mobilno se cene (tri minute, konica) nanašajo na cene mobilnega operaterja $v$ lasti vodilnega fiksnega operaterja. 
Hrovatin, Cibic, Švigelj

\section{Slovenski telekomunikacijski trg: razvoj, stanje in problemi}

- Pri cenah fiksne telefonije lahko ugotovimo, da na področju priključnine v Sloveniji uravnoteženje cen še ni končano. ${ }^{\mathbf{2 8}}$ Kot kažejo cenovne primerjave, imamo v Sloveniji mesečno naročnino, ki je za 14,4 \% nižja od minimuma v EU. Neuravnotežene so tudi cene lokalnih klicev, saj je $\vee$ Sloveniji cena klica pod minimumom EU. Zaradi tako nizkih cen mesečne naročnine in lokalnih klicev (ki so v Sloveniji hkrati medkrajevni) bi pričakovali, da bodo zato mednarodni klici dražji. Vendar ni tako, saj je Slovenija pod povprečjem EU, če za primerjavo vzamemo triminutni klic $v$ bližnjo državo in desetminutni klic $\vee$ ZDA. Konkurenčni ponudniki, ki uporabljajo internetno telefonijo (VolP) so sicer cenejši, vendar ne gre za istovrstno storitev. Tako bi torej na področju same fiksne telefonije težko govorili o navzkrižnem subvencioniranju med uporabniki, ki je veljajo za preteklost (prenizke cene domačih pogovorov in predragi mednarodni klici), uravnovešenje cen pa bo zahtevalo uskladitev navzgor. Nizke cene fiksne telefonije tudi pojasnjujejo, zakaj v Sloveniji ni večje konkurence in vstopa novih ponudnikov na trg. Tako imamo pravzaprav paradoksalen rezultat; konkurenčni rezultati so doseženi $v$ odsotnosti konkurence. Teoretično bi to lahko pojasnili tudi z obrambno taktiko oz. strateškim obnašanjem monopolnega fiksnega operaterja. Domneva, ki bi zahtevala empirično preveritev, namreč je, da je ta s predatorskimi cenami klicev (v kombinaciji z visokimi cenami medomrežnega povezovanja $\vee$ preteklosti) poskušal ohranjati monopol na trgu.

- Neuravnotežene so tudi cene dostopa do interneta (dial-up), saj je Slovenija po teh cenah tako rekoč najdražja v Evropi. Stroški dostopa do interneta $\checkmark$ Sloveniji presegajo državo EU z najvišjimi stroški za $37 \%$, če upoštevamo PPP, pa celo za 95 \%. To kaže na očitno pomanjkanje konkurence na tem segmentu storitev in na potrebo po nadaljnjem ukrepanju ATRP. $^{29}$ Čeprav za Slovenijo ni podatkov o tržnem deležu največjega ponudnika, pa iz poznavanja razmer lahko sklepamo, da ima SiOL kot hčerinska družba Telekoma Slovenije tu prevladujoč položaj.

28 Lovljenje inflacijskega sidra je bilo ob koncu leta 2002 glavna ovira doslednemu izvajanju politike uravnovešanja cen. Vlada je jeseni 2002 sprejela sklep, da se od regulatornih agencij, ki so sicer neodvisne, pričakuje, da upoštevajo tudi makroekonomske vidike (Jenko, 2002). Takšna prevlada makroekonomske politike nad samostojnostjo in neodvisnostjo regulatornih komisij je z vidika osnovnih načel regulatorne politike nesprejemljiva.

29 ATRP je leta 2002 prepovedala zaračunavanje začetnega impulza za dostop do interneta preko številk 0889 in 0880 . 


\section{Hrovatin, Cibic, Švigelj \\ Slovenski telekomunikacijski trg: razvoj, stanje in problemi}

\section{Ocena deregulacije telekomunikacij v Sloveniji in napotki za vodenje politike liberalizacije}

Ukrepe ATRP, ki vplivajo na konkurenčnost sektorja, smo prikazali v prejšnjem poglavju, zato je namen tega poglavja predvsem oceniti realne možnosti alternativnih ponudnikov storitev pri dostopu in uporabi omrežja vodilnega operaterja ter možnosti nadaljnje liberalizacije telekomunikacij tudi s spodbujanjem (neodvisnega) razvoja alternativnih infrastruktur.

$\checkmark$ Sloveniji bomo imeli tudi $v$ prihodnje - tako kot $\vee$ večini drugih razvitih držav - eno samo (fiksno) omrežje s skoraj popolnim pokrivanjem prebivalstva, to je omrežje Telekoma Slovenije. Dokler ne bo zgrajeno drugo omrežje s podobnimi lastnostmi in s podobno stopnjo pokrivanja (dosega) prebivalstva, bo treba tudi v Sloveniji uveljavljati enake ukrepe glede dostopa do omrežja, kot je praksa v drugih državah. Kot smo omenili že $\vee$ prejšnjem poglavju, je ATRP $\vee$ letu 2003 naredila odločen korak pri določanju cen zaključevanja klicev. Ocenjujemo, da sedanje cene medomrežnega povezovanja omogočajo vstop novih podjetij $\vee$ panogo, njihov obstoj in doseženi tržni delež pa bo odvisen predvsem od razmerja med stroški medomrežnega povezovanja, ki jih določa ATRP, in cenami za končne uporabnike, ki jih določa vodilni operater, ki bo ostal vodilni na trgu (market leader), in določevalec cen (price setter). Dejstvo, da je bilo ob koncu leta 2003 izdano majhno število dovoljenj, je treba pripisati tako subjektivnim faktorjem počasnosti pri uvajanju evropske zakonodaje na tem sektorju, kot objektivnim faktorjem - majhnosti trga in slabemu finančnemu zaledju (domačih) ponudnikov storitev.

ATRP je pri določanju cen medomrežnega povezovanja izbrala edino metodologijo, ki jo je imela na izbiro na kratki rok: po načelu mednarodne primerjave (benchmarking) je cene določila $\vee$ višini povprečnih cen $v$ EU. Pri določanju cen je ATRP torej izbrala boljšo od slabih možnosti: radikalen preokret $v$ razmerju med ceno zaključevanja klica in končno ceno klica za uporabnika je bil narejen zelo hitro. Namesto negativne je zdaj nastopila pozitivna razlika. Takšna pozitivna razlika je seveda predpogoj, da alternativni ponudniki pristopijo $k$ izdelavi poslovnega načrta in zbiranju finančnih sredstev. Če bi ATRP že $v$ začetku poskušala uveljaviti stroškovni pristop (stroškovno osnovane cene medomrežnega povezovanja), bi se liberalizacija na tem področju ustavila vsaj za eno leto.

Vseeno moramo opozoriti, da teorija določanja cen medomrežnega povezovanja zahteva stroškovno osnovane cene in ne cene na nivoju povprečja cen drugih držav. Prve so do operaterja omrežja in ponudnikov storitev nevtralne, druge so $v$ vsakem primeru pristranske. Če so previsoke, ne omogočajo optimalnega izkoriščanja virov, alternativne ponudnike odvračajo od vstopa $\vee$ panogo, teoretično sicer pospešujejo investiranje $\vee$ nova omrežja, vendar $\vee$ Sloveniji takšnih investicij ni realno pričakovati. Če so cene prenizke, ne omogočajo vodilnemu 


\section{Hrovatin, Cibic, Švigelj}

\section{Slovenski telekomunikacijski trg: razvoj, stanje in problemi}

operaterju potrebnega vzdrževanja omrežja in ustreznega obsega investicij. Da bi ATRP lahko $v$ naslednjem koraku odpravila pomanjkljivosti sedanjega pristopa $k$ določanju cen medomrežnega povezovanja, bi morala takoj začeti vse potrebne aktivnosti, ki bi omogočile določanje cen medomrežnega povezovanja na višini dejanskih stroškov Telekoma Slovenije.

Naj na koncu še komentiramo prepričanje, da bo že sama uvedba stroškovno osnovanih cen zaključevanja klicev omogočila vstop alternativnih ponudnikov na področje javne govorne telefonije. To prepričanje je osnovano na podmeni, da bo vodilni operater določal takšne (končne) cene klicev, da bodo alternativni operaterji lahko poslovali z dobičkom. Ker bodo novi operaterji začeli poslovati z majhnim obsegom prometa, se bo lahko zgodilo, da bo vodilni operater javne govorne telefonije določal takšne končne cene, ki zagotavljajo pokrivanje stroškov samo pri velikem obsegu prometa. Ker bo vodilni operater še dolgo ostal določevalec cen na slovenskem trgu, bodo morali alternativni ponudniki pridobivati naročnike z nižjimi cenami. Tak je večinski cenovni model alternativnih operaterjev javne govorne telefonije $\vee$ državah EU. Tako bi se lahko zgodilo, da bi vodilni operater posloval z dobičkom, alternativni operaterji pa z izgubo. Nekaj podobnega glede končnih cen opažamo na področju centreksa, če sledimo argumentom alternativnih operaterjev. Regulator mora zaradi te možnosti po našem mnenju skrbno analizirati razliko med ceno klica, ki jo zaračuna vodilni operater naročnikom, in ceno zaključevanja klica, ki jo zaračuna alternativnim operaterjem. Če je ta razlika majhna, jo mora regulator, če želi aktivno spodbuditi vstop konkurence, s svojimi ukrepi povečati. Pri tem lahko uporabi enega od znanih pristopov: cena klica minus $x$ ali cena zaključevanja klica plus $y$.

Ker je $v$ Sloveniji ATRP začela odločno posegati na telekomunikacijski trg šele $v$ letu 2003, se v strokovni in tudi širši javnosti ustvarja vtis, da je bila ustanovitev agencije prepozna in da agencija tudi prepozno uveljavlja ukrepe liberalizacije trga. Takšna razmišljanja pa ustvarjajo osnovo za napačno sklepanje, češ da bo agencija (sicer z zamudo, ampak uspešno) uveljavila takšne pogoje delovanja operaterjev, da bo mogoče na (edinem) fiksnem telefonskem omrežju vzpostaviti pošteno tekmovanje med številnimi ponudniki storitev. Da je takšno sklepanje napačno, utemeljujemo z dvema argumentoma.

- Z logičnega vidika je takšno razmišljanje nerealno, dokler je omrežje lastniško povezano s storitvami. Telekomunikacije so namreč tehnično mnogo bolj zahtevne kot železniški promet ali prenos električne energije, kjer je potreben skromen obseg predpisov za zagotavljanje prostega dostopa konkurentov do infrastrukture (omrežja), prav tako je $\vee$ teh dejavnostih mnogo manj standardov, protokolov ipd. $\vee$ telekomunikacijah lahko operater omrežja močno olajša uporabo omrežja »svojemu« ponudniku storitev oz. z izborom določenih tehnologij, protokolov ipd. praktično onemogoči uporabo omrežja drugim ponudnikom storitev. 


\section{Slovenski telekomunikacijski tro: Hrovatin, Cibic, Švigelj}

- Iz zgodovinskih izkušenj $v$ telekomunikacijsko najrazvitejših državah in državah z dolgo in relativno uspešno zgodovino regulacije telekomunikacij, pa končno iz dosedanjih neuspehov liberalizacije dostopa konkurentov do omrežja Telekoma Slovenije je jasno razvidno, da nikjer v svetu, še manj pa v Sloveniji, ni zaživela konkurenca med ponudniki storitev na omrežju vodilnega operaterja. Število razvezanih krajevnih zank je zanemarljivo, tržni deleži alternativnih ponudnikov širokopasovnega dostopa po omrežju vodilnega operaterja so prav tako nizki. Edino področje, na katerem so v nekaterih državah dosegli večje uspehe, je javna govorna telefonija.

Zaradi izkušenj drugih držav pri uvajanju konkurence na omrežju vodilnega operaterja je za uspešno liberalizacijo telekomunikacij potrebno spodbujanje (neodvisnega) razvoja alternativnih infrastruktur. Razvoj novih tehnologij je omogočil izgradnjo alternativnih omrežij, ki sprva niso bila konkurenčna fiksnemu telefonskemu omrežju telekomov: kabelska televizijska omrežja so prenašala samo televizijske signale (z izjemo Velike Britanije), mobilna telefonska omrežja pa so bila $\vee$ prvi fazi zgolj komplementarna storitev (in ne substitut) fiksnemu omrežju. Ko je razvoj tehnologije omogočil prenos podatkov (natančnejšo uporabo IP-protokola) po kabelskih televizijskih omrežjih, je $\vee$ številnih državah nastalo alternativno omrežje, ki omogoča vse storitve, ki so bile doslej monopol telekomov: prenos podatkov in prenos govora. Kjer so alternativna fiksna omrežja relativno dobro razvita, ima regulator sicer težjo, vendar hvaležnejšo nalogo: vzpostavitev enakopravnih pogojev delovanja obeh infrastruktur lahko pripelje do hitrejšega razvoja novih storitev, ki jih danes omogočajo fiksna omrežja: prenos podatkov (internet) in govora (VolP). Nekatere države so znale to prednost (dveh konkurenčnih infrastruktur) odlično izkoristiti: Belgija, Nizozemska, Švedska in Danska imajo največji doseg (penetracijo) širokopasovnega dostopa do interneta v Evropi. Iz te izkušnje lahko črpa tudi slovenski regulator. Slovenija bi torej z ustrezno politiko lahko vzpodbudila nadaljnji razvoj kabelskih omrežij. Pri tem je posebej pomembno, da kabelska omrežja ostajajo lastniško popolnoma ločena od skupine Telekoma Slovenije, ki je lastnik edinega fiksnega omrežja, saj bi lahko izkoristil svoj lastniški položaj tako, da bi kabelska omrežja še naprej ostala omejena na (enosmerni) prenos (televizijskih) signalov.

Poleg tega tudi mobilna omrežja tretje generacije zagotavljajo poleg prenosa govora (kjer bodo stroški nižji kot pri prenosu govora po omrežjih druge generacije) tudi prenos podatkov, enakovreden širokopasovnemu dostopu (po telefonskem ali kabelskem omrežju) in omejen prenos videosignalov. Drugače kot kabelska omrežja lahko mobilna omrežja tretje generacije zagotovijo visoko stopnjo pokrivanja prebivalstva s signalom. Ker bo pokritost prebivalstva s storitvami mobilnega telefonskega omrežja velika, bo to omrežje postalo drugo največje dostopno omrežje v Sloveniji. Kot smo že omenili, so v državah EU podelili vsaj 3 koncesije za 


\section{Hrovatin, Cibic, Švigelj}

\section{Slovenski telekomunikacijski trg: razvoj, stanje in problemi}

izgradnjo omrežja UMTS, v Sloveniji pa samo eno. Konkurenčno okolje, v katerem trije operaterji tekmujejo ob vstopu na trg za čim večji tržni delež, bo zagotovilo dovolj podjetniških spodbud, tako da bodo mobilna omrežja tretje generacije eden od spodbujevalcev širokopasovnega dostopa. Takšnih spodbud pa ne moremo pričakovati $\vee$ Sloveniji, kjer je bila podeljena samo ena koncesija UMTS, pa še to koncesijo je pridobilo podjetje iz skupine Telekom Slovenije. To lastniško povezanost bodo morali upoštevati tudi tisti, ki bodo oblikovali koncept privatizacije Telekoma Slovenije.

Dokler Telekom Slovenije ni privatiziran, ostaja akterjem politike na področju telekomunikacij še ena možnost - strukturna ločitev omrežja Telekoma Slovenije od dejavnosti (storitev) Telekoma Slovenije. Zanimivo je, da se ta možnost še vedno pojavlja $\vee$ razpravah, tudi $\vee$ razvitih evropskih državah (npr. predlogi za oddvojitev British Telecoma $v$ LoopCo in NetCo). Zaradi zapletenosti samega postopka razdvajanja pa ta opcija verjetno ni izvedljiva.

Po drugi strani pa je Slovenija relativno bogata tudi s hrbteničnimi omrežji. Poleg Telekomovega so za svoje potrebe omrežje zgradile še Slovenske železnice in ELES. Regionalna podjetja za distribucijo električne energije in DARS pa imajo (prva bolj, drugo manj) razvejeno kabelsko kanalizacijo, po kateri so že začela graditi optično omrežje, najprej za lastne potrebe. Kljub večkrat deklariranemu jasnemu namenu in sprejeti platformi treh stebrov (hrbtenic) $v$ slovenskih telekomunikacijah, kot jo je oblikovalo Ministrstvo RS za informacijsko družbo, ima še v letu 2003 Telekomova hrbtenična infrastruktura zelo visok tržni delež na tem področju. S problemi, ki jih opažamo pri oblikovanju novih telekomunikacijskih stebrov, lahko postane vprašljiva sama ideja "združevanja" oddelkov v obstoječih družbah. Morda bi telekomunikacijski oddelki obstoječih družb lahko hitreje prevzeli in vsaj delno uresničili nalogo vzpostavitve alternativnih ponudnikov hrbteničnih povezav $\vee$ Sloveniji.

Naj na koncu namenimo še nekaj besed privatizaciji. Privatizacija telekomunikacijskih omrežij $\vee$ Sloveniji mora uresničevati dva cilja: ne samo maksimiranje kupnine, ampak tudi ustvarjanje konkurenčne tržne strukture $v$ tej dejavnosti. Vzpostavitev drugega in tretjega stebra telekomunikacij, kot izhaja iz ukrepov vlade $v$ letu 2003, je zaradi tega nujen predpogoj kakršnekoli privatizacije Telekoma Slovenije. Pridobitev upoštevanja vrednega tržnega deleža (na trgu hrbteničnih povezav) ELESA oz. Elektro.TK na eni strani in ohranjanje ali večanje tržnega deleža kabelskih operaterjev (na trgu televizije in širokopasovnega dostopa) na drugi strani sta potrebna mejnika, ki ju mora Slovenija doseči, preden pridobi privatni kapital večinski delež v Telekomu Slovenije.

Če bodo akterji politike telekomunikacij uspešni v spodbujanju vstopa in razvoja novih telekomunikacijskih operaterjev $\vee$ Sloveniji, bo Slovenija zlahka sledila razvitosti telekomunikacijskih omrežij $v$ razvitih evropskih državah. Če bo regulatorju uspelo vzpostaviti pravilna cenovna razmerja pri virih, ki so $v$ lasti operaterjev 


\section{Hrovatin, Cibic, Švigelj \\ Slovenski telekomunikacijski trg: razvoj, stanje in problemi}

s pomembno tržno močjo, bodo tudi alternativni operaterji na trgu uspešno poslovali. Tako se bo tržna struktura na področju hrbteničnih in dostopovnih omrežij relativno hitro spreminjala v smeri večjega števila ponudnikov omrežnih storitev. Ponudniki (novih) vsebin bodo $v$ tem primeru imeli na voljo številne telekomunikacijske infrastrukture, s katerimi bodo lahko ponujali naročnikom svoje storitve: konkurenca med ponudniki omrežij bo zniževala njihove cene, kar bo dajalo dodatno spodbudo razvoju novih vsebin.

\section{Sklep}

Kljub pospešenemu ukrepanju ATRP na telekomunikacijskem trgu bo treba za zagotavljanje konkurenčnosti slovenskega trga opraviti še veliko nalog. Prihodnje naloge na področju regulacije so vezane na prilagoditev veljavne slovenske telekomunikacijske zakonodaje novi zakonodaji s področja elektronskih komunikacij, ki velja v EU od konca julija. Glavni poudarek te zakonodaje je na integriranem pristopu do trgov - trg je storitev ne glede na to, katera tehnologija jo omogoča. Zato bo osrednja pozornost namenjena opredelitvi relevantnih trgov za storitev (tako z vrsto proizvoda kot tudi geografsko) in ugotavljanju konkurenčnosti teh trgov tako statično kot tudi $v$ dinamičnem kontekstu. Regulacija bo potrebna, če nacionalna regulatorna agencija ugotovi, da na trgu ni učinkovite konkurence. Zato bo $v$ skladu z zahtevami evropske zakonodaje osrednja dejavnost slovenske ATRP morala biti usmerjena $v$ analizo trgov, določitev OPTM, kjer trgi niso konkurenčni, in posledično sprejem ukrepov za omejevanje PTM. Seveda pa, kot se je izkazalo $\checkmark$ preteklosti, sama zakonodaja ne pomeni dosti, če je $\vee$ celoti ne izvajamo. Posebna pozornost $v$ prihodnosti pa bo morala biti še naprej posvečena zagotavljanju vstopa novih ponudnikov in spodbujanju razvoja alternativnih infrastruktur, saj bo le tako prišlo do normalizacije tržne strukture.

\section{Literatura in viri}

- $\quad \operatorname{ATRP}(2003)$ : »Letno poročilo 2002«, Ljubljana.

- Blonski, M. (2002): "Network externalities and two-part tariffs in telecommunication markets ", Information Economics and Policy, 14, 1, str. 95-109.

- Cave, M. E., Majumdar, S. K., Vogelsang, I. (2002): "Handbook of Telecommunications Economics. Volume1: Structure, Regulation and Competition«, Elsevier Science B.V., Amsterdam.

- EC (2001): Annexes to the Seventh Report from the Commission on the Implementation of the Telecommunications Regulatory Package. Brussels, 26. 11. 2001, COM (2001) 706, SEC(2001) 1922.

- EC (2002): 2nd Report on Monitoring of EU Candidate Countries (Telecommunication Service Sector). ECSC-EC-EAEC, Brussels-Luxembourg, 16. 12. 2002. 


\section{Hrovatin, Cibic, Švigelj \\ Slovenski telekomunikacijski trg: razvoj, stanje in problemi}

- $\quad$ EC (2002a): Eighth Report from the Commission on the Implementation of the Telecommunications Regulatory Package. European telecoms regulation and markets 2002. Brussels, 3. 12. 2002, COM(2002) 695 final. SEC(2002) 1329.

- EC (2002b): Annex I. Market Overview. Eighth Report from the Commission on the Implementation of the Telecommunications Regulatory Package. European telecoms regulation and markets 2002. Brussels, 3. 12. 2002, COM (2002) 695 final. SEC (2002) 1329.

- EC (2002c): Annex II. Regulatory Data. Eighth Report from the Commission on the Implementation of the Telecommunications Regulatory Package. European telecoms regulation and markets 2002. Brussels, 3. 12. 2002, COM(2002) 695 final. SEC(2002) 1329.

- EC (2003): $3^{\text {rd }}$ Report on Monitoring of EU Candidate Countries. (Telecommunication Service Sector). ECSC-EC-EAEC, Brussels-Luxembourg, 16. 6. 2003.

- Gabrovšek, L. (2004): „Analiza gibanja cen mobilne telefonije v Sloveniji «, diplomsko delo, Univerza v Ljubljani, Ekonomska fakulteta.

- Hrovatin, N. (1994): „Problematika določanja cen v naravnomonopolnih javnostoritvenih panogah«, Slovenska ekonomska revija, 45, 5, str. 434-451.

- Hrovatin, N. (2001): »Regulatory Framework for EU Utilities Pricing: Legislation, Enforcement and Institutional Structure«, Working Paper N0 29, Glasgow Caledonian University, Glasgow.

- Jenko, M. (2002): „Tuje naložbe prispevajo k rasti«, Janez Šušteršič, direktor Umarja za Delo. Delo, 20. 11. 2002, str. 13.

- Kompara, Z. M. (2002): "Stop za nove Telekomove cene«, http://www.atrp.si/2akt /1akt.html, 1. 10. 2002.

- Mobitel (2003): "Razvoj mobilnih sistemov«, http://www.mobitel.si/slo/Mobilnegeneracije/1generacija/default.asp.

- Stergar, A. (2004): »Mobilcev nimajo samo še dojenčki«, Delo, 23. 1. 2004.

- Telekom Slovenije (2003): „Letno poročilo 2002«, http://www.telekom.si/index.php? page $=11454,32,51,0,0,0$.

- Uredba o metodologiji oblikovanja cen javnih telekomunikacijskih storitev in omrežij. Uradni list RS, št. 25/2002.

- Zakon o telekomunikacijah (ZTel-1). Uradni list RS, št. 30/2001.

Dr. Nevenka Hrovatin je izredna profesorica na Ekonomski fakulteti v Lljubljani, kjer tako na dodiplmski kot podiplomski ravni poučuje vrsto predmetov, med katerimi je tudi Ekonomika javnih podjetij. Pri svojem raziskovalnem delu se ukvarja z regulacijo javnega sektorja in je avtorica vrste člankov $v$ domačih in tujih revijah.

Mag. Damir Cibic je zaposlen kot višji predavatelj na Ekonomski fakulteti v Ljubljani, kjer poučuje predmet Analiza poslovanja. Pri svojem raziskovalnem delu se ukvarja s telekomunikacijami.

Mag. Matej Švigelj je zaposlen kot mladi raziskovalec na Ekonomski fakulteti v Ljubljani, kje sodeluje pri predmetih UVG (Uvod v gospodarstvo) I in II ter Ekonomiki javnih podjetij. Pri svojem raziskovalnem delu se ukvarja z regulacijo in uvajanjem konkurence $v$ energetiki in telekomunikacijah. 
Hrovatin, Cibic, Švigelj

Slovenski telekomunikacijski trg: razvoj, stanje in problemi

\section{PRILOGA}

Tabela 4: Predmet regulacije in podjetja, ki so regulirana po ZTel-1

\begin{tabular}{|c|c|c|c|}
\hline Dejavnost & Regulirano podjetje & Regulirana cena & Predmet regulacije \\
\hline $\begin{array}{l}\text { Medomrežno } \\
\text { povezovanje }\end{array}$ & $\begin{array}{l}\text { 1. operater javnega } \\
\text { fiksnega omrežja s } \\
\text { PTM (Telekom Slo- } \\
\text { venije) } \\
\text { 2. operater zakupa } \\
\text { vodov s PTM (Tele- } \\
\text { kom Slovenije) } \\
\text { 3. mobilni operaterji s } \\
\text { PTM (Mobitel, } \\
\text { Si.mobil) }\end{array}$ & $\begin{array}{l}\text { cene medomrežnega } \\
\text { povezovanja med: } \\
\text { - fiksnimi operaterji } \\
\text { - fiksnimi in mobilnimi } \\
\text { operaterji } \\
\text { - fiksnimi operaterji in } \\
\text { ponudniki ali preproda- } \\
\text { jalci storitev } \\
\text { - mobilnimi operaterji in } \\
\text { ponudniki ali preproda- } \\
\text { jalci storitev } \\
\text { - mobilnimi operaterji }\end{array}$ & $\begin{array}{l}\text { 1., 2. vzorčna ponudba } \\
\text { (RIO) v UL, zagotovitev } \\
\text { razumnega dostopa in } \\
\text { vmesnikov) (regulacija } \\
\text { ex ante) } \\
\text { 3. vzorčne ponudbe in } \\
\text { komercialne pogodbe, } \\
\text { potrebno soglasje za } \\
\text { splošne pogoje (regu- } \\
\text { lacija ex post na osno- } \\
\text { vi pritožb) }\end{array}$ \\
\hline $\begin{array}{l}\text { Razvezan dostop } \\
\text { do krajevne zanke } \\
\text { za fiksno javno } \\
\text { telekomunikacijsko } \\
\text { omrežje } \\
\text { - (skupna uporaba } \\
\text { objektov operaterja } \\
\text { s PTM) } \\
\text { - (odprt dostop do } \\
\text { omrežij oz. storitev) }\end{array}$ & $\begin{array}{l}\text { operater javnega } \\
\text { fiksnega omrežja s } \\
\text { PTM (Telekom Slove- } \\
\text { nije) }\end{array}$ & $\begin{array}{l}\text { cene za dostop do krajev- } \\
\text { ne zanke (denarno nado- } \\
\text { mestilo) }\end{array}$ & $\begin{array}{l}\text { - vzorčna ponudba } \\
\text { - stroškovne cene } \\
\text { - javno objavljeni } \\
\text { objektivni pogoji } \\
\text { - sprotno in temeljito } \\
\text { odgovarjanje na zah- } \\
\text { teve po dostopu }\end{array}$ \\
\hline $\begin{array}{l}\text { Zakupljeni vodi } \\
\text { (in potrebni vmesniki) }\end{array}$ & $\begin{array}{l}\text { operaterji zakupa } \\
\text { vodov s PTM (Tele- } \\
\text { kom Slovenije) }\end{array}$ & cene zakupljenih vodov & vzorčna ponudba (RIO) \\
\hline $\begin{array}{l}\text { Druge dejavnosti - } \\
\text { nudenje javnih fik- } \\
\text { snih telekomunika- } \\
\text { cijskih storitev }\end{array}$ & $\begin{array}{l}\text { operater javnega } \\
\text { fiksnega omrežja s } \\
\text { PTM (Telekom } \\
\text { Slovenije) }\end{array}$ & $\begin{array}{l}\text { druge cene storitev: } \\
\text { - cene pogovorov v } \\
\text { fiksnem javnem tele- } \\
\quad \text { komunik. omrežju } \\
\text { - naročnina } \\
\text { - priključnina } \\
\text { - internet }\end{array}$ & $\begin{array}{l}\text { stroškovna naravna- } \\
\text { nost cen v skladu z } \\
\text { zakonom oz. (v praksi) } \\
\text { benchmarking }\end{array}$ \\
\hline Univerzalne storitve & $\begin{array}{l}\text { ponudnik univerzalnih } \\
\text { storitev: Telekom } \\
\text { Slovenije }\end{array}$ & cene univerzalnih storitev & $\begin{array}{l}\text { - obseg storitev } \\
\text { - dostopnost cen } \\
\text { - kakovost storitev }\end{array}$ \\
\hline
\end{tabular}

Vir: ZTel-1. 


\section{SUMMARY}

\section{Slovenian Telecommunications Market: Develop- ment, State and Problems}

The telecommunication industry is without a doubt the key industry of the future and not surprisingly, governments, researchers and investors alike are devoting much attention to this industry. In the last decades the telecommunications industry has been characterised by changes in every aspect. These changes have already transformed the way people work and live, and they will influence people's lives in the future as well. Changes in telecommunication industry include technology changes as well as changes in the market structure. Regarding technology changes, we should especially stress the importance of digitalization which has caused the introduction of new products and convergence between information technology and telecommunications. On the other hand, the monopoly structure with one telephone company has changed into a structure of various, competing companies. All these changes have been accompanied with legislative and regulatory developments and expansions of independent national regulatory agencies.

Slovenia has also taken steps to the liberalization of the telecommunications market with the gradual introduction of new legislation. In Slovenia liberalization of telecommunications in comparison with the EU started relatively late. The monopoly for fixed voice telephony was formally abolished at the beginning of 2001. On the other hand, an independent regulator (ATRP) was established in the second half of 2001.

The Slovenian telecommunication market is, in terms of revenues, worth 600 million euros, which represents $2.6 \%$ of the Slovenian GDP. Although the market is small both in absolute and in relative terms, the market segments are similar to those in the EU. However, the share of the mobile market is dominant and exceeds the average mobile share in the EU as well as in the EUCC. Moreover, in terms of mobile penetration, Slovenia is a leading country when compared to benchmarking countries and it exceeds the EU average by ten percentage points.

In Slovenia there are three operators (two of them with SMP) and one provider in the market for mobile services, which is comparable to selected benchmark countries from the EU and the EUCC. Nevertheless, the Slovenian mobile market is more concentrated than in the $\mathrm{EU}$, because the leading operator has a market share that exceeds $70 \%$, while the leading operators in ten countries of the EU do not exceed a $50 \%$ market share. The reasons for the concentrated market structure in the Slovenian mobile telephony 
market is in the late granting of licences to competing firms and relatively high interconnection prices between operators. Similar anomalies as with the GSM concessions were observed when UMTS licences were granted. Currently only the leading operator has been given the licence, which may lead to a similar result in terms of market shares as in the GSM technology.

In comparison with benchmarking countries, Slovenia is quite unique in the fixed telephony market with no competition challenging the state owned monopoly operator Telekom Slovenia. Nevertheless, the comparison of incumbent tariffs for rental charges, national and international calls shows that tariffs are among the lowest ones and below the EU average or even below minimum tariff levels in the EU. On the other hand, in the past high prices of interconnection were lowered to the EU average as late as in $\mathrm{Au}$ gust 2003 after the ATRP took measures.

With the introduction of an independent regulatory agency (ATRP), which takes care of competition and regulation of telecommunications, Slovenia follows a prevailing model in the area of energy and telecommunications in the EU. ATRP is facing many problems in its operations. Its independence was severely limited by the Government in 2002, when the regulators were given a task to follow the inflation goals. In Slovenia the price cap form of regulation is statutorily used. However, the independent regulatory agency, being preoccupied with its formation and the lack of experienced economic staff, still relies on benchmarking (e.g. for interconnection charges), which is gradually being abolished in the EU countries. In spite of prompt actions by the ATRP, there is still a lot of work to be done to assure the competition in the market. On the other hand, beside suitable regulation of the access to the bearer's network, it is necessary to stimulate further liberalization of telecommunications with stimulating the development of alternative infrastructures.

Further tasks in the field of regulation are linked to adjusting the current Slovene telecommunication law to the new electronic communications law that has been valid in the EU since July. The main emphasis of this law is in the integrated access to the markets. Therefore, the attention is on determining relevant markets for a service (type of product and geographic targets) and on ascertaining the competitiveness of those markets in static as well as in dynamic contexts. Regulation will be necessary if the national regulatory agency finds out that there is no effective competition in the market. Therefore, in accordance with European legislation the main activity of ATRP will have to be oriented towards market analysis, definition of the operators with SMP where markets are not competitive and consequently taking measures to limit the operators with SMP. As it was shown in the past, legislation by 
Hrovatin, Cibic, Švigelj

Slovenski telekomunikacijski trg: razvoj, stanje in problemi

itself is not worth much if it is not carried out in total. Special emphasis in the future will furthermore have to be dedicated to assuring entrance to new providers and stimulating the development of alternative infrastructures, since this is the only way that will lead to normalization of the market structure. 